\title{
KAJIAN ETNOBOTANI MASYARAKAT SUKU USING KABUPATEN BANYUWANGI
}

\section{STUDY ETHNOBOTANY OF USING ETHNIC AT BANYUWANGI REGENCY}

\author{
N. Nurchayati' ${ }^{1)}$, Fuad Ardiyansyah' ${ }^{2)}$ \\ Program Studi Biologi Fakultas MIPA Universitas PGRI Banyuwangi \\ Email: nnurchayati99@gmail.com
}

\begin{abstract}
ABSTRAK
Penggunaan tanaman dalam suku Using masih sangat tinggi terutama di bidang pengobatan, pangan, ritual, seni arsitektur maupun kerajinan. Seiring perkembangan teknologi, pengetahuan tanaman suku Using semakin terkikis. Penelitian ini bertujuan untuk mengungkap pengetahuan tentang pemanfaatan tumbuhan oleh masyarakat Using Kabupaten Banyuwangi. Penelitian dilakukan di lima kecamatan. Penelitian ini merupakan penelitian deskriptif eksploratif menggunakan metode wawancara terstruktur dan semi terstruktur. Hasil dari penelitian menunjukkan jumlah tanaman yang dimanfaatkan sebanyak 78 spesies dan tergabung dalam 41 famili. Tanaman sebagai bahan pangan utama hanya 1 jenis. Tanaman sebagai bahan pangan tambahan berjumlah 39 jenis. Tanaman sebagai bahan jamu dan obat sejumlah 44 jenis tanaman. Tanaman sebagai simbol ritual sebanyak 27 tanaman. Tanaman sebagai bahan bangunan sebanyak 12 jenis. Tanaman sebagai bahan kerajinan sebanyak 17 jenis.
\end{abstract}

Kata Kunci: Etnobotani, tanaman, suku Using

\begin{abstract}
Using the plants in "Using" tribe is very high, especially in the medicine sector, food, rituals, architectural arts and crafts. Along with the development of technology, plant knowledge of Using tribe more eroded. So the researcher considers that it is necessary to conduct research on " Study Ethnobotany of "Using" Ethnic at Banyuwangi Regency" which aims to reveal about ethnobotany knowledge of "Using" people at Banyuwangi Regency. This research was done in five subdistricts. This research is a descriptive explorative study that uses structured and semi-structured interview methods. The results of the study showed that the number of plants that used amounted to 78 species belonging to 41 families. Plants as the staple food are only 1 species. Plants as additional food are 39 species. Plants as medicinal are 44 species. Plants as ritual symbols are 27 species. Plants as building materials are 12 species. Plants as craft materials are 17 species.
\end{abstract}

Keywords : Ethnobotany, plant, "Using" ethnic 


\section{PENDAHULUAN}

Suku Using merupakan salah satu suku yang terkenal dengan bahasa dan budayanya yang beragam. Suku ini mendiami wilayah kabupaten Banyuwangi dan bermukim di 9 kecamatan dari 24 kecamatan yang ada di kabupaten Banyuwangi yaitu Banyuwangi (kota), Glagah, Giri, Kabat, Rogojampi, Songgon, Singojuruh, Cluring dan Genteng. Komunitas Using yang masih memegang teguh adat-istiadat terdapat pada 5 kecamatan yang meliputi Glagah, Giri, Kabat, Rogojampi dan Singojuruh. Suku Using memiliki ragam budaya yang terealisasi dalam aneka upacara adat atau ritual. Hampir di semua kawasan suku Using masih ditemui pengobatan dengan menerapkan pijat, mantra dan pengobatan herbal menggunakan tanaman. Suku Using memiliki sejarah pengobatan dengan memanfaatkan sumber daya alam yang berlimpah. Pertanian suku Using juga memiliki hasil yang beragam. Cara pengelolaan pertanian yang mereka lakukan memiliki kearifan lokal tersendiri dengan memanfaatkan tanaman. Kerajinan dan seni arsitektur bangunan yang ada di suku Using banyak juga yang memanfaatkan tanaman (Anoegrajekti N, dkk, 2016).

Perkembangan zaman dan teknologi serta meningkatnya taraf pendidikan masyarakat menyebabkan kecenderungan generasi muda untuk memandang sebelah mata terhadap kebudayaan leluhur. Hal ini berdampak menurunnya pengetahuan masyarakat dalam pemanfaatan ragam tumbuhan. Pengetahuan leluhur terkait pemanfaatan tanaman hanya menjadi pengetahuan lisan, sehingga generasi penerus tidak banyak mengetahui manfaat tanaman. Kearifan lokal masyarakat dikhawatirkan akan cepat hilang seiring menyusutnya keanekaragaman tanaman itu sendiri. Dengan demikian perlu dilakukan penelitian untuk memperkenalkan kembali ragam pemanfaatan tanaman di wilayah Suku Using dan melihat bagaimana implikasinya bagi konservasi lingkungan. Peneliti merasa perlu melakukan penelitian dengan judul “Etnobotani Masyarakat Suku Using Kabupaten Banyuwangi”. Tujuan dari penelitian ini adalah untuk mengungkap pengetahuan tentang pemanfaatan tumbuhan oleh masyarakat Suku Using Banyuwangi.

\section{METODE}

Penelitian ini merupakan penelitian deskriptif eksploratif yang menggunakan metode wawancara terstruktur dan semi terstruktur. Penelitian dilakukan pada bulan 
Maret sampai Mei 2018. Lokasi penelitian berada pada 5 kecamatan yang meliputi: 1) Kecamatan Glagah (Kemiren, Glagah, Taman Suruh, Bakungan, Mandaluko, Olehsari, Kenjo, Dukuh Kopen Kidul); 2) Kecamatan Giri (Cungking Mojopanggung, Boyolangu); 3) Kecamatan Kabat (Macan putih, Kejoyo); 4) Kecamatan Rogojampi (Aliyan); 5) Kecamatan Singojuruh (Alas Malang). Alat dan bahan yang dipergunakan dalam penelitian ini adalah kamera, alat perekam dan alat tulis .

Menurut Nur Irsyad (2013), penentuan informan kunci didasarkan pada penguasaan pengetahuan masyarakat. Berdasarkan kriteria tersebut maka dipilih informan yang meliputi tokoh masyarakat (25 Orang), orang yang dianggap memiliki pengetahuan tentang keanekaragaman tanaman (80 Orang), petani (60 Orang), pengrajin (20 Orang) dan pelaku budaya (15 Orang). Penelitian ini dilakukan dalam beberapa tahapan. Tahap awal penelitian adalah studi pendahuluan yang dilakukan dengan melakukan observasi lapangan terkait wilayah yang akan dijadikan lokasi penelitian dan studi literatur. Tahap kedua adalah studi etnobotani yang meliputi survei lapangan dan wawancara kepada responden. Penentuan responden menggunakan snowball sampling. Tahap ketiga adalah pengumpulan data tanaman yang disebutkan oleh responden pada tahap dua. Pengumpulan data tanaman dilakukan dengan melihat langsung tanaman yang disebutkan oleh responden, kemudian menuliskan pada tabel perekam dan melakukan identifikasi tanaman untuk mengetahui ilmiah serta familinya. Upaya untuk memudahkan identifikasi dilakukan dengan mendokumentasikan tanaman dan bagian-bagiannya serta membuat herbarium tanaman. Tahap keempat adalah analisis data berupa pengelompokan tumbuhan bermanfaat bagi suku Using berdasarkan habitus dan manfaatnya dalam beberapa kegunaan (Martin G. J. 2004).

\section{HASIL DAN PEMBAHASAN}

\section{Keanekaragaman Tanaman}

Hasil dari survei etnobotani diketahui bahwa jumlah tanaman yang dimanfaatkan oleh masyarakat suku Using Banyuwangi adalah sebanyak 78 tanaman. Jumlah famili dari tanaman tersebut adalah 41 famili. Jumlah famili dengan anggota terbanyak meliputi Zingiberaceae (9), Poaceae (8), Euphorbiaceae (6), Solanaceae (4), Fabaceae (3), dan Piperaceae (3). Berikut adalah perbandingan jumlah enam famili dengan jumlah anggota terbanyak: 


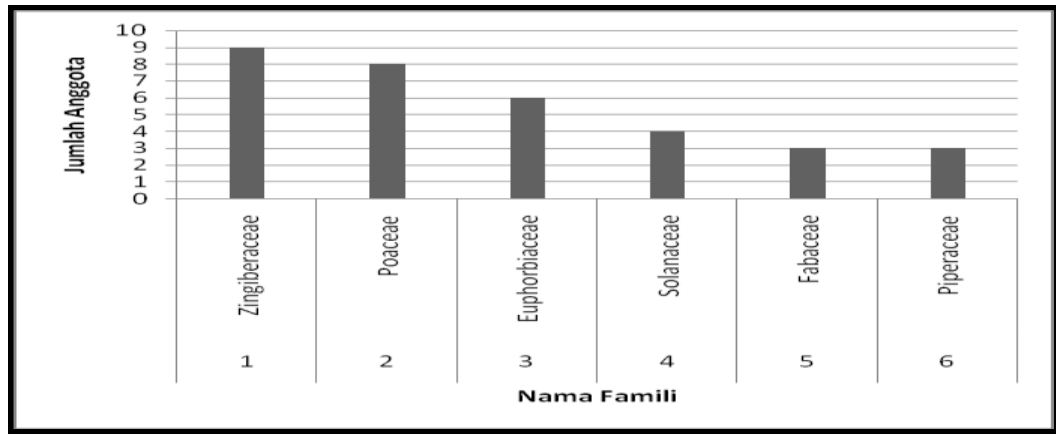

Gambar 1. Perbandingan Jumlah Spesies Tanaman Bermanfaat berdasarkan Familinya Berdasarkan data tersebut dapat diketahui bahwa tumbuhan yang paling banyak dimanfaatkan adalah dari famili Zingiberaceae dengan jumlah spesies sebanyak 9. Diantara meliputi: 1) lengkuas (Alpinia galangal L. Willd.) ; 2) kunyit putih (Curcuma alba L.); 3) kunyit (Curcuma domestica L.); 4) jahe (Zingiber officinale L.); 5) temu lawak (Curcuma xanthorrhiza L.); 6) kencur (Kaempria galanga L); 7) temu kunci (Boesenbergia rotunda L.); 8) lempuyang (Zingiber aromaticum); 9) wesah (Amomum dealbatum). Tanaman dari famili Zingiberaceae banyak dimanfaatkan sebagai tanaman obat maupun pelengkap bumbu masakan.

Habitus tanaman bermanfaat di suku Using dibedakan menjadi: 1) pohon; 2) perdu; 3) semak; 4) terna atau herba. Habitus tanaman merupakan penampakan atau perawakan dari suatu tanaman. Habitus tanaman dibedakan atas pohon, perdu, semak dan terna. Tanaman memiliki habitus pohon jika memiliki diameter batang lebih dari 20 $\mathrm{cm}$ dan tinggi mencapai $6 \mathrm{~m}$. Habitus perdu dimiliki oleh tanaman rendah di bawah $6 \mathrm{~m}$ dan percabangannya berasal dari pangkal batang. Semak adalah habitus tanaman rendah yang menempel tanah atau dari golongan rumput-rumputan. Sedangkan habitus terna dimiliki oleh tanaman yang berbatang lunak. Berikut adalah rekapitulasi jumlah tanaman berdasarkan habitusnya:

Tabel 1. Rekapitulasi Jumlah Spesies Tanaman Berguna Berdasarkan Habitusnya

\begin{tabular}{clc}
\hline No & Habitus & Jumlah \\
\hline 1 & Pohon & 21 \\
2 & Perdu & 22 \\
3 & Semak & 14 \\
4 & Terna & 21 \\
\hline
\end{tabular}

Hasil rekapitulasi tersebut menunjukkan bahwa tanaman bermanfaat di suku Using kabupaten Banyuwangi banyak yang memiliki habitus perdu yaitu sejumlah 22 
tanaman. Berikut adalah perbandingan antar habitus tanaman bermanfaat di suku Using Kabupaten Banyuwangi :

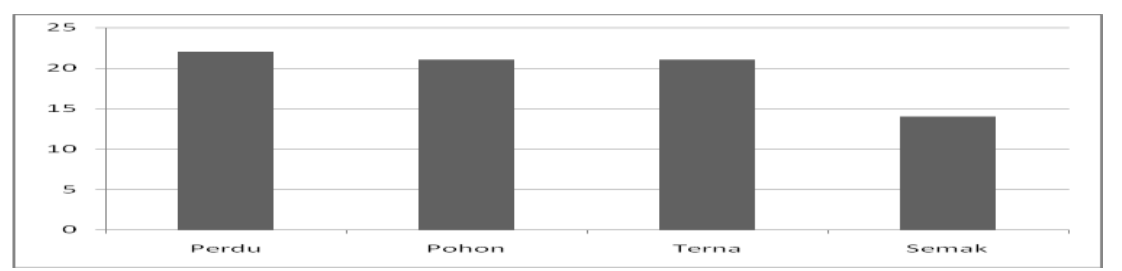

Gambar 2. Perbandingan Jumlah Spesies Tanaman Bermanfaat di Suku Using Kabupaten Banyuwangi Berdasarkan Habitusnya

Berdasarkan grafik diketahui bahwa habitus tanaman yang paling banyak dimanfaatkan adalah tanaman dengan habitus perdu, Terbanyak ke dua yang dimanfaatkan adalah dari golongan habitus pohon dan terna. Ketiga habitus tanaman tersebut dimanfaatkan baik sebagai tanaman obat, pangan, tanaman hias maupun ritual. Hal ini sesuai dengan pernyataan menurut Oktaviana (2008) bahwa tanaman obat paling banyak digunakaan memiliki habitus perdu, pohon dan terna.

\section{Kategori Pemanfaatan Tanaman Berguna}

Hasil penelitian menunjukkan bahwa tanaman yang dimanfaatkan untuk memenuhi kepentingan masyarakat using Kabupaten Banyuwangi sebanyak 78 tanaman. Kategori pemanfaatan meliputi pemenuhan kebutuhan pangan, obat, ritual, dan bahan kerajinan. Pemanfaatan tanaman sebagai bahan pangan dibedakan lagi menjadi makanan utama, makanan tambahan yang meliputi umbi-umbian, sayursayuran, buah-buahan, biji-bijian dan kacang-kacangan, bahan minuman dan bumbu dan aroma masakan. Kategori pemanfaatan tanaman oleh masyarakat Suku Using Kabupaten Banyuwangi adalah sebagai berikut:

Tabel 2. Kategori Pemanfaatan dan Jumlah Jenis Tanaman

\begin{tabular}{llc}
\hline No & \multicolumn{1}{c}{ Kategori Pemanfaatan Jenis Tanaman } & Jumlah \\
\hline 1 & Makanan utama atau makanan pokok & 1 \\
\hline 2 & Makanan tambahan & 3 \\
\hline & a. Umbi-umbian & 11 \\
\hline & b. Sayur-sayuran & 7 \\
\hline & c. Buah-buahan & 3 \\
\hline & d. Biji-bijian dan kacang-kacangan & 15 \\
\hline & e. Bumbu dan aroma masakan & 2 \\
\hline 3 & Bahan minuman beraroma & 44 \\
\hline 4 & Bahan jamu dan obat & 27 \\
\hline 5 & Simbol ritual & 4 \\
\hline 6 & Bahan bangunan &
\end{tabular}




\begin{tabular}{lll}
\hline 7 & Bahan kerajinan & 17 \\
\hline
\end{tabular}

Tabel 2 menunjukkan bahwa pemanfaatan tanaman oleh masyarakat suku Using di kabupaten Banyuwangi paling banyak adalah untuk memenuhi kebutuhan jamu dan obat, yaitu sebesar 44 jenis. Sedangkan untuk memenuhi kebutuhan pangan adalah sebanyak 38 jenis.

\section{a. Tanaman Bahan Pangan Utama Suku Using di Kabupaten Banyuwangi}

Kategori bahan pangan dalam penelitian ini dibedakan atas: 1) bahan pangan utama atau makanan pokok; 2) bahan pangan tambahan. Berdasarkan hasil penelitian dapat diketahui bahwa tanaman yang digunakan sebagai bahan makanan utama hanya 1 yaitu padi (Oryza sativa).

\section{b. Tanaman Bahan Pangan Tambahan dan Minuman beraroma Suku Using Kabupaten Banyuwangi}

Bahan makanan tambahan oleh Suku Using di kabupaten Banyuwangi dibedakan atas beberapa kategori. Kategori pertama adalah untuk memenuhi kebutuhan umbi-umbian yaitu sebanyak 3 tanaman yang meliputi: 1) Ubi jalar (Ipomoea batatas); 2) ketela pohon (Manihot esculenta); 3) kentang (Solanum tuberosum).

Kategori kedua adalah untuk memenuhi kebutuhan sayur-mayur yaitu sebanyak 11 tanaman. Tanaman yang dimanfaatkan sebagai sayur-mayur yaitu: 1) daun semanggi (Marsilea crenata); 2) daun beluntas (Pluchea indica) 3) daun dan buah kelor (Moringa cleifera L); 4) daun kangkung (Ipomoea aquatic); 5) buah kecipir (Psopocarpus tetragonolobus L); 6) daun ketela pohon (Manihot esculenta); 7) tunas bambu (Bambusa sp.); 8) terong (Solanum melongena L); 9) buah mentimun (Cucumis sativum); 10) daun dan buah kacang panjang ( Vigna cylindrica L); 11) daun katu (Sauropus androgynus).

Kategori ketiga adalah makanan tambahan berupa buah-buahan yaitu sebanyak 7 tanaman. Tanaman yang dimanfaatkan oleh suku Using untuk memenuhi kebutuhan buah-buahan meliputi: 1) buah papaya (Carica papaya L); 2) buah alpukat (Perseae americana Mill); 3) buah sirsak (Annona muricata L.); 4) buah nangka (Arthocarpus heterophyllus L.); 5) buah mangga (Mangifera indica L); 6) buah mentimun (Cucumis sativum); 7) buah pisang (Musa paradisiacal L). 
Kategori keempat adalah makanan tambahan berupa biji-bijian dan kacangkacangan sebanyak 3 tanaman. Pada penelitian ini tanaman yang digunakan untuk memenuhi kebutuhan pangan berupa biji-bijian dan kacang-kacangan meliputi: 1) ketan (Oryza glutinosa L; 2) kacang tanah (Arachis hypogaea L); 3) Jagung (Zea mays L).

Kategori kelima adalah makanan tambahan untuk memenuhi bahan bumbu dan aroma masakan, yaitu sebanyak 15 tanaman. Hasil dari penelitian menunjukkan tanaman yang berguna sebagai bahan bumbu dan aroma masakan meliputi: 1) buah kelapa (Cocos nucifera L); 2) buah asam jawa (Tamarindus indica L.); 3) buah belimbing wuluh (Averrhoa bilimbi L); 4) umbi bawang merah (Allium cepa L); 5) umbi bawang putih (Allium sativum L.); 6) daun salam (Syzygium polyanthum L.); 7) daun pandan betawi (Dracaena angustifolia L.); 8) daun pandan wangi (Pandanus amaryllfolius L.); 9) daun serai (Cymbopogon citratus L); 10) buah dan daun jeruk nipis (Citrus aurantifolia L); 11) buah cabai (Capsicum fustescens L); 12) rimpang lengkuas (Alpinia galangal L. Willd.), 13) rimpang kunyit (Curcuma domestica L.); 14) rimpang jahe (Zingiber officinale L.); 15) rimpang kencur (Kaempria galanga L.).

Kategori keenam adalah tanaman yang berguna untuk minuman beraroma. Dalam penelitian ini tanaman yang berguna untuk memenuhi kebutuhan minuman sebanyak 2 tanaman, yaitu: 1) kopi (Coffea arabica); 2) jahe (Zingiber officinale L.).

\section{c. Tanaman Obat dan Bahan Jamu pada Suku Using Kabupaten Banyuwangi}

Hasil wawancara dengan responden terpilih dari suku using di wilayah Banyuwangi menunjukkan bahwa penyakit yang dapat diobati dengan tanaman disajikan pada tabel berikut:

Tabel 3. Rekapitulasi Kategori penggunaan tanaman obat dan Jumlah Jenis Tanaman

\begin{tabular}{llc}
\hline No & \multicolumn{1}{c}{ Jenis Penyakit } & Jumlah Jenis Tanaman \\
\hline 1 & Obat perawatan wanita & 6 \\
\hline 2 & Penurun panas & 5 \\
\hline 3 & Penambah nafsu makan & 4 \\
\hline 4 & Obat mata & 3 \\
\hline 5 & Kanker & 5 \\
\hline 6 & Diabetes & 6 \\
\hline 7 & Penyakit kulit & 6 \\
\hline 8 & Obat batuk & 8 \\
\hline 9 & Pegal linu & 1 \\
\hline 10 & Sariawan & 1 \\
\hline 11 & Radang persendian & 1 \\
\hline
\end{tabular}




\begin{tabular}{|c|c|c|}
\hline No & Jenis Penyakit & Jumlah Jenis Tanaman \\
\hline 12 & Sakit gigi & 2 \\
\hline 13 & Obat luka & 4 \\
\hline 14 & Antibiotik & 4 \\
\hline 15 & Wasir & 3 \\
\hline 16 & Batu ginjal & 3 \\
\hline 17 & Rematik & 2 \\
\hline 18 & Darah tinggi & 3 \\
\hline 19 & Kolesterol & 3 \\
\hline 20 & Bisul & 2 \\
\hline 21 & Kandung kemih & 1 \\
\hline 22 & Sakit perut, diare, gangguan pencernaan & 7 \\
\hline 23 & Asma & 1 \\
\hline 24 & Perawatan rambut & 1 \\
\hline 25 & Asam urat & 2 \\
\hline 26 & Antiseptik & 1 \\
\hline 27 & Anemia & 1 \\
\hline 28 & Masuk angin & 1 \\
\hline 29 & Liver & 1 \\
\hline 30 & Keseleo & 1 \\
\hline
\end{tabular}

Berdasarkan tabel di atas, masyarakat Suku Using paling banyak menggunakan tanaman untuk mengobati penyakit batuk, sakit perut, diare, gangguan pencernaan, perawatan wanita, penyakit kulit dan diabetes.

Masyarakat Suku Using Kabupaten Banyuwangi seringkali mengkonsumsi tanaman obat dalam bentuk jamu. Jamu merupakan obat tradisional yang diwariskan oleh nenek moyang secara turun temurun. Suku Using sendiri banyak mengolah tanaman menjadi jamu dari famili Zingiberaceae, yang meliputi temu lawak (Curcuma anthorrhiza L.), kunyit (Curcuma domestica L.), kunyit putih (Curcuma alba L.), jahe (Zingiber officinale L.), kencur (Kaempria galanga L.), temu kunci (Boesenbergia rotunda $\mathrm{L}$ ), dan lempuyang (Zingiber aromaticum $\mathrm{L}$ ).

Organ dari tanaman yang digunakan oleh suku Using untuk obat meliputi daun sebanyak 22 jenis, bunga sebanyak 3 jenis, buah sebanyak 7 jenis, biji sebanyak 1 jenis, akar sebanyak 2 jenis, umbi sebanyak 2 jenis dan rimpang sebanyak 9 jenis. Berikut ini adalah perbandingan penggunaan organ tanaman untuk tanaman obat. 


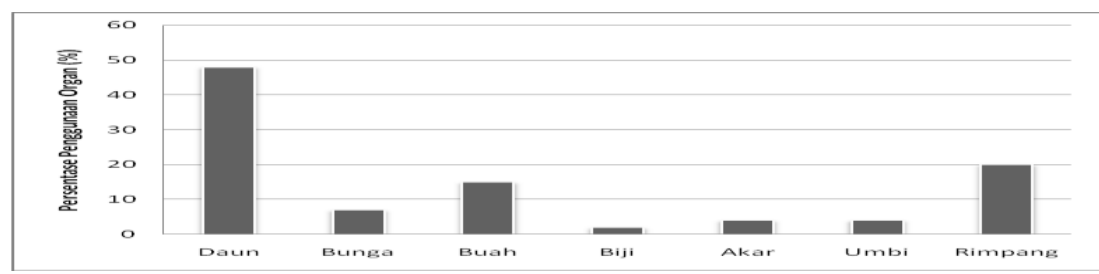

Gambar 3. Grafik Perbandingan Penggunaan Organ tanaman untuk Pengobatan oleh Masyarakat Suku Using Kabupaten Banyuwangi

Berdasarkan grafik tersebut dapat diketahui organ yang paling banyak digunakan untuk obat adalah daun dan rimpang. Hal ini dikarenakan pada daun dan rimpang banyak terdapat senyawa alkaloid dan flavonoid. Senyawa alkaloid merupakan senyawa organik yang banyak berasal dari alam. Senyawa alkaloid ini memiliki keaktifan biologis dan efek fisiologis. Sedangkang flavonoid merupakan metabolit sekunder dari jaringan tanaman yang ditandai dengan adanya zat warna. Senyawa ini berperan sebagai antioksidan, antikanker, antiinflamasi, antialergi dan antihipertensi (Fauziah, 2010).

\section{d. Tanaman Simbol Ritual Suku Using Kabupaten Banyuwangi}

Suku Using kabupaten Banyuwangi sangat terkenal dengan ritual yang masih terjaga. Menurut Indiarti W (2013), pelaksanaan ritual banyak menggunakan tanaman untuk berbagai simbol. Hasil penelitian menunjukkan bahwa ritual yang dilaksanakan oleh Suku Using Kabupaten Banyuwangi ada 10 kegiatan ritual. Berikut ini adalah data tanaman yang digunakan untuk ritual beserta jenis ritualnya:

Tabel 4. Rekapitulasi Daftar Ritual pada Suku Using Banyuwangi dan Tanaman yang Berperan

\begin{tabular}{lllc}
\hline No & Nama Ritual & \multicolumn{1}{c}{ Asal Daerah } & $\begin{array}{c}\text { Jumlah Spesies Tanaman } \\
\text { yang digunakan }\end{array}$ \\
\hline 1 & Kebo-keboan & Alas malang, Aliyan & 24 \\
\hline 2 & Geredoan & Macan putih, Kejoyo & 8 \\
\hline 3 & Gelar Pitu & Kopen Dukuh & 13 \\
\hline 4 & Gelar Songo & Glagah & 18 \\
\hline 5 & Sapi-sapian & Kenjo & 15 \\
\hline 6 & Ider Bumi & Kemiren, Mandoluko & 18 \\
\hline 7 & Seblang & Oleh sari, Bakungan & 21 \\
\hline 8 & Puter Kayun & Boyolangu & 6 \\
\hline 9 & Bersih desa & Mojopanggung & 9 \\
\hline 10 & Tumpeng Sewu & Kemiren & 29 \\
\hline
\end{tabular}

Kategori tanaman ritual yang digunakan dibedakan atas sesaji, selametan gebratan, dan lainnya. Berdasarkan hasil penelitian dapat diketahui bahwa acara ritual kebo-keboan memanfaatkan 24 jenis tanaman. Tanaman tersebut meliputi sirih (Piper 
betle $\mathrm{L}$ ), gambir (Uncaria gambir $\mathrm{H})$, pinang (Areca cetachu L), tembakau (Nicotiana tabacum), puring (Codiaeum variegatum L), mawar (Rosa sp.), melati (Jasminum sambac L), kanthil (Magnolia $x$ alba L), kenanga (Cananga odorata), kunyit (Curcuma domestica L.), padi (Oryza sativa), ketan (Oryza glutinosa L), pandan betawi (Dracaena angustifolia L), kelapa (Cocos nucifera L), ubi jalar (Ipomoee batatas L), ketela pohon (Manihot esculenta L), kentang (Solanum teberosum L), jagung (Zea may L), pisang (Musa paraaadisiaca), kangkung (Ipomoee aquatica L), kacang panjang (Vigna cylindrica L.), kecipir (Psopocarpus tetragonolobus), semanggi (Marsilea crenata $\mathrm{L}$ ), alang-alang (Impetara cylindrical L.).

Ritual geredoan menggunakan tanaman sebagai simbol ritual sebanyak 8 tanaman, meliputi kacang panjang (Vigna cylindrica L), kunyit (Curcuma domestica L.), cabai (Capsicum frustescens), kluwih (Arthocarpus camansi), tauge (Phaseolus aureus), jeruk limau (Citrus amblycarpa), alang-alang (Impetara cylindrical L.).

Ritual gelar pitu memanfaatkan 13 jenis tanaman. Rincian tanaman tersebut meliputi kacang panjang (Vigna cylindrica L), kacang tanah (Arachis hypogeae), cabai (Capsicum frustescens), talas (Colocasia esculenta)), ubi jalar (Ipomoee batatas), kelapa (Cocos nucifera), kemiri (Aleurites moluccanus), pandang wangi (Pandanus amaryllifolius), alang-alang (Impetara cylindrical L).

Ritual Gelar songo menggunakan tanaman sejumlah 18 jenis. Diantaranya kacang tanah (Arachis hypogeae), padi (Oryza sativa), kanthil (Magnolia $x$ alba L), kenanga (cananga odorata), bawang putih (Allium sativum), cabai (Capsicum frustescens), mawar (Rosa sp.), talas (Colocasia esculenta), ubi jalar (Ipomoee batatas L), bambu (Bambusa sp.), pisang (Musa paradisiaca), jagung (Zea mays).

Ritual sapi-sapian menggunakan 15 tanaman. Rincian tanaman tersebut adalah kacang panjang (Vigna cylindrica L), kacang tanah (Arachis hypogeae), mawar (Rosa sp.), kamboja (Plumeria sp.), sedap malam (Polianthes tuberosa), talas (Colocasia esculenta), ubi jalar (Ipomoee batatas L), pandan (Dracaena angustifolia L), ketela pohon (Manihot esculenta), gambir (Uncaria gambir $\mathrm{H})$, aren (Arenga pinnata), bunga kertas (Baugenvillea sp.), melati (Jasminum sambac), dan pinang (Areca cetachu L).

Ritual ider bumi menggunakan tanaman 18 tanaman. Tanaman tersebut meliputi kacang panjang (Vigna cylindrica L), kacang tanah (Arachis hypogeae), bawang putih (Allium sativum), cabai (Capsicum frustescens), kanthil (Magnolia $x$ alba 
L), selada (Nasturtium officinale), kangkung (Ipomoee aquatica L), gempol (Nauclea orientalis), kelapa (Cocos nucifera L), kemiri (Aleurites moluccanus), tauge (Phaseolus aureus), singkong (Manihot esculenta), kelor (Moringa oleifera), bayam (Amaranthus sp.), jeruk limau (Citrus amblycarpa).

Ritual seblang memanfaatkan 21 tanaman. Tanaman tersebut meliputi padi (Oryza sativa), kelapa (Cocos nucifera), kentang (Solanum tuberosum), kanthil (Magnolia $x$ alba L), bawang merah (Allium cepa), bawang putih (Allium sativum), cabai (Capsicum frustescens), sirih (Piper betle L), pisang raja (Musa paradisiaca), tembakau (Nicotiana tabacum), mawar (Rosa sp.), kamboja (Plumeria sp.), kenanga (Cananga odorata), selada (Nasturtium officinale), kangkung (Ipomoee aquatica L), tomat ranti (Solanum lycopersicum), bamboo (Bambusa sp.), puring (Codiaeum variegatum $\mathrm{L}$ ), gambir (Uncaria gambir $\mathrm{H})$, bunga kerta (Baugenvillea sp.).

Ritual puter kayun memanfaatkan 9 tanaman yang meliputi kacang tanah (Arachis hypogeae), padi (Oryza sativa), cabai (Capsicum frustescens), kelapa (Cocos nucifera L), tauge (Phaseolus aureus), jeruk limau (Citrus amblycarpa). Ritual bersih desa menggunakan tanaman kecipir (Psopocarpus tetragonolobus), cabai (Capsicum frustescens), bambu (Bambusa sp.), tauge (Phaseolus aureus), koro putih (Canvanalia sp.), labu siam (Sechium edule), buncis (Phaseolus vulgaris), pare (Momordica harantia), labu kuning (Curcubita moschata).

Ritual tumpeng sewu memanfaatkan 28 tanaman yaitu kelapa (Cocos nucifera L.), cabai (Capsicum frustescens), bawang merah (Allium cepa), bawang putih (Allium sativum), kacang tanah (Arachis hypogaea), kencur (Kaempferia galangal), jeruk limau (Citrus amblycarpa), kemiri (Alleurites moluccanos), ketan (Oryzae glutinosa), ketela pohon (Manihot esculenta), pisang (Musa paradisiaca), alang-alang (Imperata cylindrica), waru (hibiscus tiliaceus), klampes (Ocimum sanctum), koro (Canvanalia sp.), buncis (Phaseolus vulgaris), terong (Solanum melongena), labu siam (Sechium edule), kacang panjang (Vigna cylindrica L), katu (Sauropus androgynus), pare (Momordica harantia), selada air (Nasturtium officinale), kangkung (Ipomoee aquatica L), ubi jalar (Ipomoea batatas), labu kuning (Curcubita moschata), bentul (Colocasia esculenta), gembili (Dioscorea esculenta), kentang (Solanum tuberosum).

\section{e. Tanaman Bahan Bangunan Suku Using Kabupaten Banyuwangi}


Selain kebutuhan pokok berupa pangan, manusia juga membutuhkan tempat tinggal sebagai kebutuhan primer. Bangunan rumah banyak memanfaatkan bagian dari tanaman. Suku Using di Kabupaten Banyuwangi memanfaatkan jenis tanaman tertentu untuk bangunan rumah. Menurut Anggriyanti L (2010), tanaman sangat berguna untuk memenuhi kebutuhan dari bagian-bagian bangunan rumah. Penggunaan tumbuhan dan bagian tumbuhan untuk bangunan oleh Suku Using disajikan pada tabel 5 berikut:

Tabel 5. Penggunaan Tumbuhan pada Bagian bangunan Masyarakat Suku Using Banyuwangi

\begin{tabular}{|c|c|c|}
\hline No & $\begin{array}{c}\text { Bagian } \\
\text { Bangunan }\end{array}$ & Nama Spesies \\
\hline 1 & Atap & $\begin{array}{l}\text { Kelapa (Cocos nucifera), jati (Tectona grandis L), Nangka } \\
\text { (Arthocarpus integra) }\end{array}$ \\
\hline 2 & Pintu dan Jendela & Jati (Tectona grandis L), mahoni (Swetenia mahagoni), \\
\hline 3 & Lantai & Jati (Tectona grandis L), Sono (Albizia chinensis) \\
\hline 4 & Tiang & $\begin{array}{l}\text { Bendo (Artocarpus elasticus), Kelapa (Cocos nucifera), Jati } \\
\text { (Tectona grandis L), nangka (Artocarpus integra) }\end{array}$ \\
\hline 5 & Plafon & Bendo (Artocarpus elasticus), kelapa (Cocos nucifera) \\
\hline 6 & Reng & Mahoni (Swetenia mahagoni) \\
\hline 7 & Begisting & $\begin{array}{l}\text { Asem (Tamarindus indica), randu (Ceiba petandra), sengon } \\
\text { (Albizia chinensis) }\end{array}$ \\
\hline
\end{tabular}

\section{f. Tanaman Sebagai Bahan Kerajinan}

Hasil dari penelitian berupa wawancara dengan responden, kerajianan masyarakat suku Using dibedakan atas beberapa kategori. Kategori tersebut meliputi ukiran, alat musik, perkakas rumah tangga, anyaman, topeng barong, pewarna batik dan seni kerajinan tasbih. Tanaman yang berperan dalam mendukung seni kerajinan masyakat suku Using disajikan pada tabel 6 berikut:

Tabel 6. Penggunaan Tanaman pada Seni Kerajinan Masyarakat Suku Using Banyuwangi

\begin{tabular}{lll}
\hline No & Kategori Kerajinan & \multicolumn{1}{c}{ Nama Spesies } \\
\hline 1 & Ukiran & $\begin{array}{l}\text { Jati (Tectona grandis L), Mahoni (Swetenia } \\
\text { mahagoni) } \\
\text { Jati (Tectona grandis L), mahoni (Swetenia } \\
\text { mahagoni), kelapa (Cocos nucifera), nangka } \\
\text { (Arthocarpus integra) }\end{array}$ \\
& $\begin{array}{l}\text { Perkakas rumah tangga/ } \\
\text { hiasan }\end{array}$ & $\begin{array}{l}\text { Kelapa (Cocos nucifera), Mahoni (Swetenia } \\
\text { mahagoni), bambu (Bambusa sp.) }\end{array}$ \\
3 & Alat musik & $\begin{array}{l}\text { Pule (Alstonia scholaris) } \\
\text { Bambu (Bambusa sp.), Mangir (Ganophyllum } \\
\text { falcatum), gebang (Corypha utan) }\end{array}$ \\
\hline
\end{tabular}




\begin{tabular}{lll}
\hline No & Kategori Kerajinan & \multicolumn{1}{c}{ Nama Spesies } \\
\hline 6 & Pewarna Batik & Kulit pohon asam (Tamarindus indica), biduri \\
& & (Calotropis gigantea), daun jati (Tectona grandis \\
& & L), santen, daun mangga (Mangifera indica), \\
& & kemuning (Murraya peniculata), kulit manggis \\
& & (Garcinia mangostana) \\
7 & Tasbih & Cermei londo (Phyllathus acidus) \\
\hline
\end{tabular}

Berdasarkan tabel 6 tersebut, kerajinan berupa ukiran, perkakas rumah tangga dan hiasan, seni barong memanfaatkan bagian batang dari tanaman.

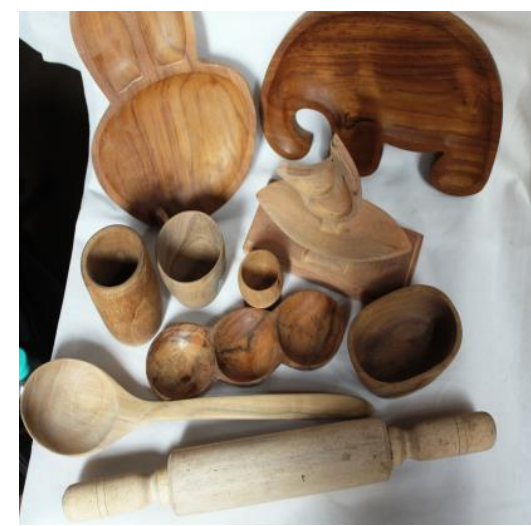

a

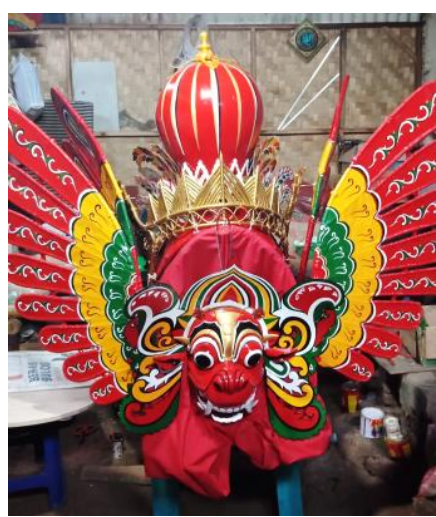

b

Gambar 4. a) Ukiran dan Perkakas b) Barong Hasil Kerajinan Suku Using Banyuwangi Kerajianan berupa alat musik memanfaatkan bagian temperung kelapa dan batang dari mahoni.

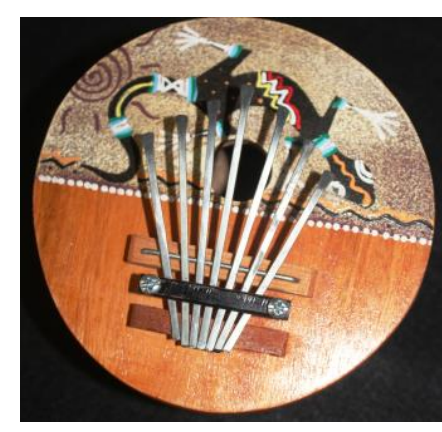

a.

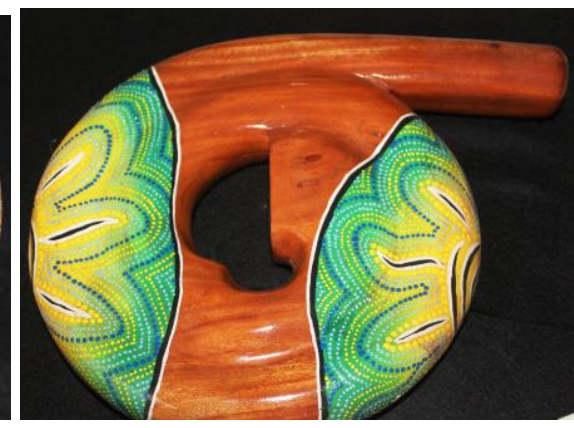

b

Gambar 6. Alat Musik a) Karimba dan b) Jolidu dari Alas Malang Suku Using Banyuwangi 

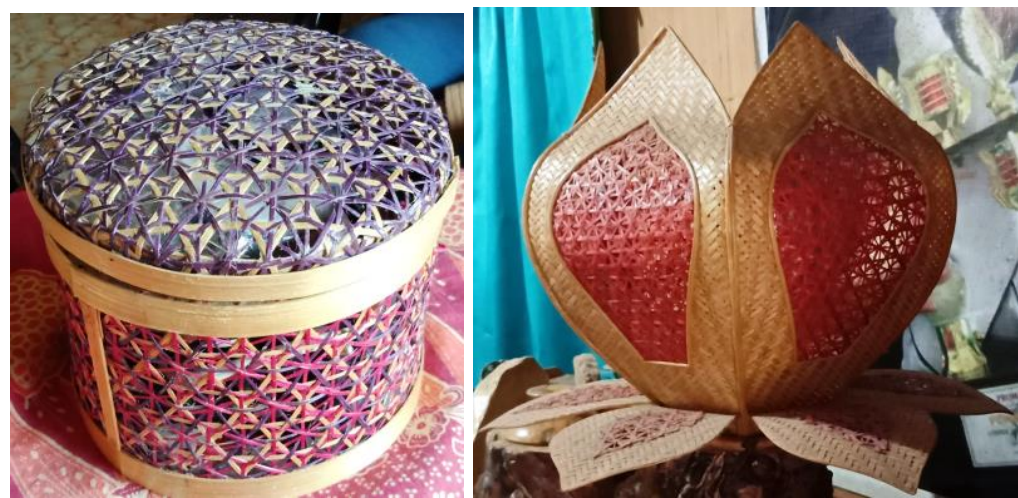

Gambar 7. Anyaman Hasil Kerajinan Suku Using Banyuwangi

Kerajinanan anyaman memanfaatkan serat, kulit dan sayatan dari batang tanaman. Pewarna batik menggunakan kulit batang, daun, dan buah. Bagian tanaman yang dimanfaatkan untuk pewarna batik disesuaikan dengan warna yang ingin di hasilkan. Tasbih dibuat dari biji tanaman cermei londo (Phyllathus acidus).

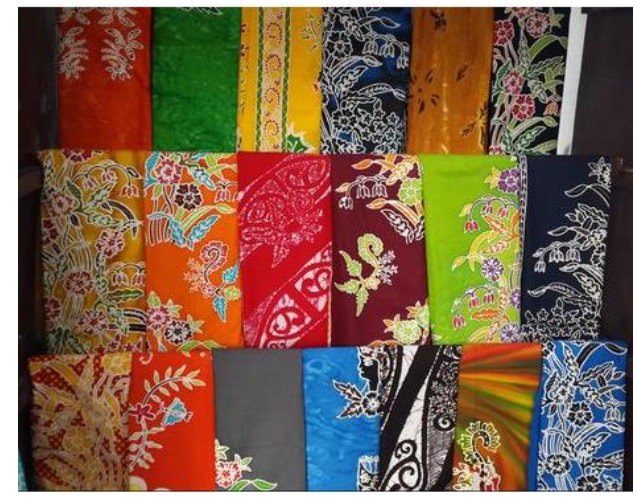

Gambar 8. Kerajinan Batik Gajah Oling Khas Banyuwangi

\section{KESIMPULAN DAN SARAN}

Kesimpulan hasil penelitian ini adalah

1. Tanaman berguna yang dimanfaatkan oleh masyarakat suku Using Kabupaten Banyuwangi sebanyak 78 spesies yang tergabung dalam 41 Famili. Habitus tanaman tersebut meliputi pohon, perdu, semak dan perdu. Kategori pemanfaatan meliputi bahan pangan utama, bhan pangan tambahan, bahan minuman beraroma, bahan jamu dan obat, simbol ritual, bahan bangunan dan kerajinan

2. Tanaman sebagai bahan pangan utama hanya 1 jenis tanaman. Tanaman sebagai bahan pangan tambahan berjumlah 39 jenis dan dibedakan atas kategori umbiumbian, sayur- mayor, buah-buahan, biji-bijian dan kacang-kacangan serta bumbu dan aroma masakan. Tanaman sebagai bahan jamu dan obat sejumlah 44 jenis 
tanaman. Tanaman sebagai simbol ritual sebanyak 27 tanaman. Tanaman sebagai bahan bangunan sebanyak 12 tanaman. Tanaman sebagai bahan kerajinan sebanyak 17 tanaman

Saran dalam penelitian ini :

1. Perlu dilakukan penelitian dan pengkajian mendalam untuk tanaman yang belum banyak dimanfaatkan oleh Suku Using Banyuwangi dengan sampel yang lebih luas

2. Perlu dilakukan pengkajian untuk tanaman obat yang mamiliki khasiat sebagai anti oksidan, anti inflamasi dan anti bakteri,

\section{DAFTAR PUSTAKA}

Anoegrajekti N, dkk, 2016. Kebudayaan Using: Konstruksi, Identitas dan Pengembangannya. Ombak. Yogyakarta

Angriyantie L. 2010. Etnobotani dan Potensi Tumbuhan Berguna di Kampung Keay, Kabupaten Kutai Barat, Kalimantan Timur. Skripsi. Departemen Konservasi Sumberdaya Hutan dan Ekowisata. Fakultas Kehutanan. IPB. Bogor

Fauziah I, 2010. Isolasi dan Identifikasi Senyawa Flavonoid dari Ketela Pohon (Manihot utilissima pohl.). http://miss-purplepharmacy.blogspot.com. Diakses tanggal 15 Oktober 2018

Indiarti W. dkk. 2013. Pengembangan Program Desa Wisata dan Ekowisata Berbasis Partisipasi Masyarakat Desa Kemiren Kabupaten Banyuwangi. Badan Perencanaan Pembangunan. Laporan Bersumberdana APBD Kabupaten Banyuwangi.

Oktaviana LM. 2008. Pemanfaatan Tradisional Tumbuhan Obat Oleh Masyarakat Di Sekitar Kawasan Cagar Alam Gunung Tilu, Jawa Barat (Skripsi). Bogor (ID): Institut Pertanian Bogor.

Nur Irsyad. dkk. 2013. Studi Etnobotani Masyarakat Desa Sukolilo Kawasan Pegunungan Kendeng Pati Jawa Tengah. Jurnal Penelitian. Bioma Vol 15 No 1. Hal 27-34

Martin G. J. 2004. Etnobothany A Method Manual. Chapman and Hall. London

Tim Peneliti Antropologi UGM. 2008. Menyibak Ranah Using: Sebuah Catatan Etnografis Masyarakat Using. Yogyakarta: UGM. 